\title{
ANALYZING SEVERAL FACTORS THAT INFLUENCE PEOPLE TO MAKE LOANS ONLINE
}

\author{
Marta Widian Sari ${ }^{a *)}$, Andry Novrianto ${ }^{a)}$ \\ ${ }^{a)}$ Putra Indonesia University YPTK, Padang, Indonesia \\ ${ }^{*}$ Corresponding Author: marta.widiansari@gmail.com
}

Article history: received 20 August 2020; revised 29 August 2020; accepted 20 September 2020

\begin{abstract}
The purpose of this study was to determine the influence of cultural factors and psychological factors on people's decisions to apply for online loans (fintech) with religious factors as an intervening variable. The population in this study were the people of West Sumatra. The research sampling method was 100 people using quota sampling. Data processing with SmartPLS 3.0. The results of this study are Cultural Factors mediated by Religious Factors on Community Decisions to Apply for Online Loans (Fintech) and Psychological Factors mediated by Religious Factors on Community Decisions to Apply for Online Loans (Fintech).
\end{abstract}

Keywords: cultural factors; psychological factors; community decisions to apply for online loans (fintech); religious factors

\section{INTRODUCTION}

Economic progress in a country will provide a direct picture of the increasing needs of its people. This is because the situation and conditions that are seen today can be a great opportunity. Many people really need funds from third parties in order to meet all the needs of the community [1], [2]. The sources of these funds can come from outside, namely by taking credit which is currently known as a loan/credit. With a culture that is currently changing rapidly, one of the most important needs in society is internet access [3]. With the development of technology, currently there is a loan/credit for the community in the form of submitting loan funds that do not bother the public to come to the bank [4]. This shows that the habit in the past has begun to leave society and has become a new habit in borrowing funds, namely borrowing online. This impulse arises from them because they see changes in other societies. A person's psychology is also influenced by the surrounding environment which makes them aware that they will also do the same thing so they don't look out of date [5]. Ease of loan/credit can be done online which we can easily access via internet access. Apart from banks, many Fintech institutions are currently emerging names as financial technology that is of great interest to millennials.

Opportunities in Fintech or finance on this technology are still wide open. According to [6] and according to [7] Financial Technology also referred to as FinTech, is a new financial service model developed through information technology innovation. At present, advances in technology and including internet access that are developing rapidly cannot be prevented that support this. Technology provides great opportunities, one of which is the online loan business which is currently very circulating in the community [8]. The internet is also used as a medium for transactions which will make it easier for us as business people to run a business that they always offer in goods and services to their consumers. This also has an effect on changes in business in the financial sector known as fintech (financial technology [9]. This has increased quite a drastic increase in online loans to meet people's financial needs such as applying for online loans to banks/Fintech institutions in the form of investment loans or working capital loans [10].

Meanwhile, people in general face difficulties in the economy because of the many demands that exist such as daily necessities that they must fulfill, so they can take this type of consumptive loan. Consumptive loans are loans that can be used for consumption or for personal needs [11]. And all this can be done now through fintech (financial technology) facilities. With the development of technology and permits for digital transactions, online lending institutions (Fintech) have also developed, there are so many online lending institutions that exist today, on the one hand this online lending institution can provide assistance to the community, but on the other hand this online lending institution causing many losses to the community such as providing convenience but not educating people with online lending (Fintech). Not only a matter of education, but religiously loans/credit have also been regulated in religion. Starting from Islam to other religions. However, here it will be more clearly discussed about the religion of Islam in regulating loans/credit [12]. All loans/credits made by conventional banks are haram because they use the interest system. Interest is the same as usury. So when people are mainly Muslim, they will consider when the loan/credit is in the form of usury which is prohibited by religion. However, this will also be seen from a person's religious level. The more obedient a person is in their religion, especially Islam, the more they will avoid interest or usury [13].

And also ranging from very high interest/margin from loans to dependence and embarrassment of customers by calling all lists of contact names on the customer's number. Of course the decision to make an online loan is based on various kinds of regulations, but sometimes people do not 
carry out a thorough analysis because of the first need, because of the convenience provided by the lure of customers through advertisements, and lies in providing the amount of funds that most people are still in the ordinary. about online lending (Fintech). So that it causes many losses because the online loan institution is not registered with the OJK/unofficial. Even though the OJK itself has announced unofficial online loans (Fintech), they still try and in the end many regret their decision to borrow online [14].

Therefore this research was conducted to determine the factors that influence people to apply for online loans. And this will also be the cause of this research and other research so that it is expected to produce factors that can be a reference or consideration in making decisions for related parties and the development of research in the field of Fintech.

\section{Fintech (Financial Technology)}

According to Nizar [15] Financial Technology (FinTech) is a combination of technology and financial features or it can also be interpreted as innovation in the financial sector with a touch of modern technology. And according to Dofeitner et.al. [16], FinTech is a very fast and dynamic industry where there are many different business models. Furthermore, according to Mildawati [17], Financial Technology, also referred to as FinTech, is a new financial service model developed through information technology innovation. So according to the author, Financial Technology is a public financial service that combines technology and finance where this service will provide innovation to business.

Types of Financial Technology (Fintech) According to Siti Kholifah [18] There are three types of financial technology, namely:

1. Third-party payment systems Examples of third-party payment systems are cross-border EC, online-to-offline $(\mathrm{O} 2 \mathrm{O})$, mobile payment systems, and payment platforms that provide services such as bank payments and transfers.

2. Peer-to-Peer (P2P) Lending Peer-to-Peer Lending is a platform that brings together lenders and lenders via the internet. Peer-to-Peer Lending provides credit and risk management mechanisms. This platform helps lenders and borrowers meet their individual needs and make efficient use of money.

3. Crowdfunding Crowdfunding is a type of FinTech where a concept or product such as a design, program, content and creative work is publicly published and for people who are interested and want to support the concept or product can provide financial support. Crowdfunding can be used to reduce entrepreneurial financial needs, and predict market demand.

Strengths and Weaknesses of Financial Technology (FinTech) According to Santi [19] the advantages of Fintech are:

1. Serving Indonesians who have not been served by the traditional financial industry due to strict banking regulations and the limitations of the traditional banking industry in serving people in certain areas.

2. To become an alternative to funding other than traditional financial industry services where people need a more democratic and transparent alternative to financing.

Meanwhile, the disadvantages of Fintech are:

1. Fintech is a party that does not have a license to move funds and is less well-established in running its business with large capital, when compared to banks.

2. Some Fintech companies do not yet have physical offices, and lack of experience in carrying out procedures related to security systems and product integrity.

Financial Technology (FinTech) Challenges According to the Financial Services Authority (2016), the challenges in Fintech are:

1. Regulations in Support of FinTech Development. Adopt regulations regarding digital signatures and the use of digital documents so as to optimize the potential of the FinTech industry.

2. Coordination between related agencies and ministries. To optimize the potential of FinTech with a complex business environment, support is also needed from various related ministries and agencies.

Financial Technology (FinTech) Risks According to the Financial Services Authority (2016), the risks experienced by FinTech users. So a strategy is needed to protect consumers and national interests. The strategies for protecting consumers are as follows:

1. Protection of user funds Potential loss or decline in financial capacity, whether due to abuse, fraud, or force majeure from FinTech activities.

2. Protection of user data Privacy issues of FinTech users are prone to data misuse, whether intentional or unintentional (hacker or malware attacks) The strategies to protect national interests are as follows:

a. Anti Money Laundering and Terrorism Financing Prevention (APU-PPT) The ease and speed offered by FinTech creates potential abuse for money laundering and terrorism financing activities.

b. Financial System Stability It is necessary to have adequate risk management so as not to have a negative impact on financial system stability.

\section{Cultural Factors}

Cultural factors According to Susanto [20] cultural factors have a broad and deep influence on purchasing behavior, these cultural factors include; culture, sub-culture, and social class ". 1). Saying that, "culture is the determinant of the most basic desires and behavior". Culture begins with habits. Culture is a way of life that is developed and shared by a group of people and is passed down from generation to generation. Culture is made up of many complex elements, including religious and political systems, customs, language, tools, clothing, buildings and works of art. Therefore, everyone who moves to a new area needs to learn the local culture. According to Firdaus et. al. [21], "culture is a collective programming of thoughts that differentiates members of one category of people from other categories". 
According to Sendari [22], five cultural dimensions are identified as follows: a) Power distance, concerning the level of equality of society in power. A small power distance indicates an equal society. b) Individualism vs collectivism, regarding ties in society, in a society where each individual party is expected to take care of himself and his family independently. c) Masculinity vs femininity, concerning the differences in style between the two sexes. In men the emphasis is on assertiveness and competitiveness, while in women it is politeness and attention. d) Uncertainty avoidance, concerning the sense of comfort in a culture towards uncertainty. e) Long-term orientation, concerning the mindset of the community. In a society with a long-term orientation, the highlights are status, thriftiness, and persistence and a high level of shame. 2). Sub-culture Each culture consists of smaller sub-cultures which provide more special characteristics and socialization for its members. Sub-culture consists of nationality, religion, racial group and geographic area.

When subcultures become large and affluent enough, companies often design marketing programs specifically to serve them. "Many sub-cultures make up important market segments, and marketers often design products and marketing programs tailored to their needs" [23]. Social Class Basically, all societies have social strata. The stratification sometimes takes the form of a caste system where members of different castes are raised with certain roles and cannot change their caste membership. Stratification is more often found in the form of social class. According to Kotler [24], social class is "a relatively homogeneous and permanent division of society, which is arranged hierarchically and whose members share similar values, interests, and behaviors".

\section{Psychological Factors}

Psychological factors A person's psychological state is influenced by many things. According to Allport in Carapedia, psychological is "the thoughts, feelings, and behavior of individuals who are influenced by the actual, imagined, or indirect presence of other people", whereas according to Titchener and Wundt in Carapedia, "psychological is human experience learned from the point of view of personal point of view who experienced it. According to Kotler [24], a person's purchase choices are influenced by four main psychological factors, namely motivation, perception, learning, and beliefs and attitudes. 1). Motivation Motivation is a drive or impetus in a person to do and achieve a goal. A person has many needs at any given time. Kotler [24], psychologists have developed theories of human motivation. Three well-known theories, namely; the theory of Sigmund Freud, Abraham Maslow, and Frederick Herzberg. 2). Perception A person who is motivated is ready to act. How someone who is motivated to act will be influenced by 118 Among Makarti Vol.6 No.12, December 2013, their perception of certain situations. According to Kotler [24], "perception is a process used by an individual to select, organize, and interpret information input in order to create a meaningful world picture". Perception does not only depend on physical stimuli, but also depends on the environment and circumstances of the individual concerned. Perceptions can vary widely from one individual to another even though they experience the same reality. Setiadi [23] says, "the key word in the definition of perception is the individual. Everyone will look at the situation in a different way, people can have different perceptions of the same object ".

Perception has a subjective nature. Perceptions that are formed by a person are influenced by thoughts and the environment around them. According to Setiadi [23], perception is formed by three influences: $\bullet$ Characteristics of stimuli; - Relationship stimuli with their environment; - The conditions within ourselves. 3). Learning When people act, they gain knowledge. Learning includes changes in a person's behavior that arise from experience. Most of human behavior is the result of learning. Learning theorists believe that learning is produced through a working combination of encouragement, stimulation, action, response and reinforcement. Learning theory teaches marketers that they can build demand for a product by tying it to strong impulses, using motivational cues, and providing positive reinforcement [24]. Beliefs and Attitudes Through acting and learning, one gains beliefs and attitudes. Both then influence their buying behavior. According to Kotler [24], "belief is a description of one's thoughts about the picture of something".

People's beliefs about a product or brand influence their purchasing decisions. Marketers are very interested in the beliefs that people have in their minds about their products and brands. Brand belief is in the memory of consumers. Attitudes are evaluations, emotional feelings, and the tendency for actions that are favorable or unfavorable and last a long time in a person towards certain objects or ideas. People have a certain attitude towards almost everything; religion, politics, clothing, music, food, and others. Attitude puts all that into a frame of mind that likes or dislikes an object. Attitudes cause people to behave quite consistently towards similar objects [24].

\section{Community Decisions Submitting Online Loans (Fintech)}

This is an advantage in itself and at the same time a challenge, especially related to a number of online loan collection problems that have recently been in the spotlight. Online loans that ended up with a number of problems. It is very important to always be careful when applying for an online loan, you can even access this one service easily and quickly [25]. Although there are hundreds of fintechs that can be found online, in reality not half of these companies are registered with the OJK [26]. This certainly deserves a special consideration for you, before finally deciding to access the wrong Fintech, especially online loans.

In order to avoid the trap of irresponsible online loans, here's how to make it safe if you borrow at online loan fintechs [27] :

1. Check whether the official license is registered with the OJK 
2. See Transparency of Information Provided

3. Do not be easily tempted by the fast and practical process

4. Read and Understand the Contract Agreement Well

5. Apply Safely and Pay Off in a Timely

\section{Religious Factors}

Religiosity comes from the word religiosity which means shifth, great devotion to religion. Religiosity comes from religion related to religion or the religious nature inherent in a person. Religiosity, according to Schiffman and Kanuk [28], has played an important role in the Jewish community in the United States in influencing product buying decisions. The Jewish community in America considers the halal issue to be an important matter in choosing a product to consume. The same thing is also found in Indonesia based on several studies which found the tendency of Muslim consumers to consider the problem of halal in choosing products to consume. Al-Ghazali in Zainuddin [29] suggests a method of educating children by giving examples, training and habituation then advice and suggestions as an educational tool in order to foster children's personalities in accordance with religious teachings. Based on some of the descriptions above, the operational definition in this study is what is meant by religious-based primary school education (religiosity) is an elementary school education that uses the primary school curriculum but is added with a religion-based curriculum.

\section{RESEARCH METHODS}

The method used is explanatory survey. Descriptive data collection was carried out on 100 people of West Sumatra, the sampling technique used was proportional random sampling. Data analysis was carried out by several sources, both secondary data and primary data, such as data combining answers to each question in the questionnaire, which revealed questions about cultural factors, psychological factors, religious factors and social decisions to apply for online loans. Structural analysis tools using SmartPLS 3.0. The reason for choosing this method is because of its ability to measure constructs indirectly through indicators and simultaneously analyze indicator and latent variables, and the relationship between latent variable indicators, as well as the relationship between variables and other variables, along with the involvement of measurement errors. The results of this study are expected to provide an overview of the clarity of the relationship and the magnitude of the influence of variables which are very useful for exploring in detail the various factors that influence people's decisions to apply for online loans in order to provide a comprehensive understanding. This understanding is related to efforts to increase public knowledge in Fintech, especially in online lending.

\section{RESULTS AND DISCUSSION}

After the estimated model meets the Outer Model criteria, the structural model (Inner model) is then tested.
Following are the R-Square values in the construct:

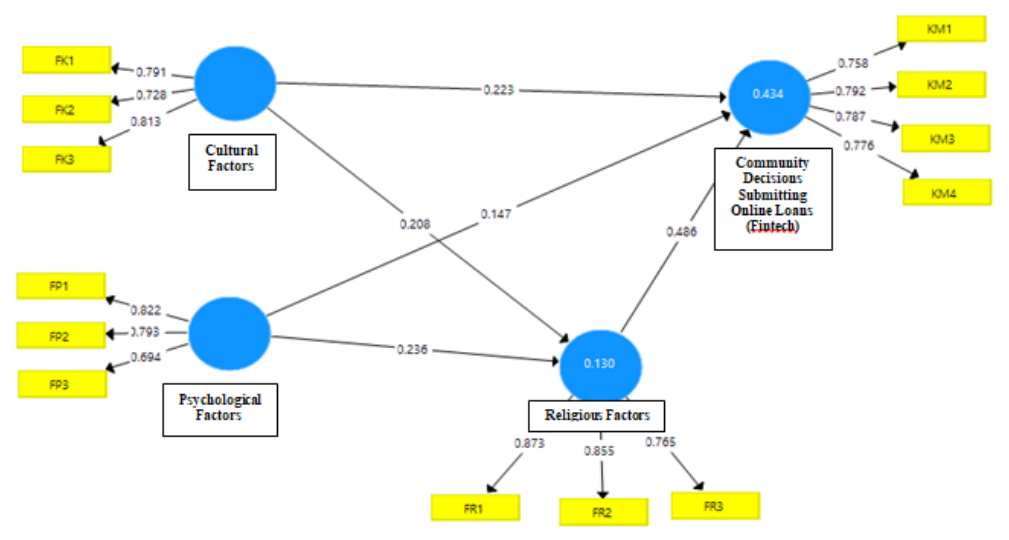

Figure 1. R-Square

Figure 1 above shows the R-Square value of the Religious Factor construct of 0.130 or $13 \%$ which illustrates the magnitude of the influence it receives from the construct of the Religious Factor from the construct of the Cultural Factor and the Psychological Factor or is the simultaneous influence of the construct of Cultural Factors and Psychological Factors on the Religious Factors of society. . Meanwhile, the R-Square value for the construct of Community Decisions to Apply for Online Loans is 0.434 or $43.4 \%$, indicating the magnitude of the influence exerted by Cultural Factors, Psychological Factors and Religious Factors in explaining or influencing Community Decisions to Apply for Online Loans The higher the R-Square value, the greater the ability of the exogenous construct to explain endogenous variables so that the better the structural equations are formed.

The hypothesis testing is as figure 2. Figure 2 shows that the relationship between cultural factors and people's decisions to apply for online loans has a positive and significant effect with a T-statistic of 2.596 (> 1.96). Thus, the hypothesis H1 in this study which states that "Cultural factors influence the Community's Decision to Apply for Online Loans" is accepted. Then the relationship between psychological factors and the community's decision to apply for online loans is positive and insignificant, with a Tstatistic of $1.611(<1.96)$. Thus the H2 hypothesis in this study which states that "Psychological factors do not affect the Community's Decision to Apply for Online Loans" is rejected. The relationship between cultural factors and religious factors has a positive and significant effect with a T-statistic of 2.165 (> 1.96). Thus, the hypothesis H3 in this study which states that "Cultural factors influence religious factors" is accepted. Then the relationship between psychological factors and religious factors is positive and significant with a T-statistic of 2.547 (> 1.96). Thus, the hypothesis H4 in this study which states that "Psychological factors influence religious factors" is accepted. Furthermore, the relationship between Religious Factors and Community Decisions to Apply for Online Loans is positive and significant with a T-statistic of 6.208 (> 1.96). Thus, the hypothesis $\mathrm{H} 5$ in this study which states that "Religious 
factors influence people's decisions to apply for online loans" is accepted.

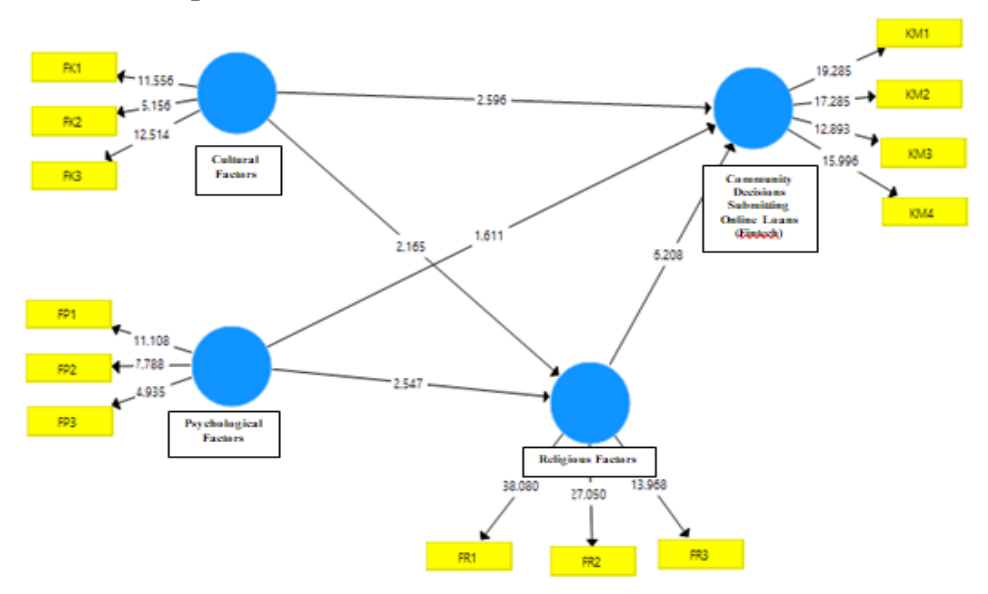

Figure 2. Hypothesis Test

Table 1

Relationship between Model I and Model II

\begin{tabular}{l|r|r|r|r|c|} 
& Original Sampl... & Sample Mean (... & Standard Devia... & TStatistics (|O/... & P Values \\
\hline Faktor Kebuda... & 0.101 & 0.104 & 0.049 & 2.063 & 0.040 \\
\hline Faktor Psikolog... & 0.115 & 0.120 & 0.051 & 2.261 & 0.024 \\
\hline
\end{tabular}

Furthermore, Model I, the relationship between Cultural Factors and Community Decisions to Apply for Online Loans with Religious Factors as an intervening variable is positive and significant with a T-statistic of 2.063 (> 1.96). Thus the hypothesis H6 in this study which states that "Cultural Factors are mediated by Religious Factors on Community Decisions to Apply for Online Loans" is accepted. And then Model II the relationship between Psychological Factors on Community Decisions to Apply for Online Loans with Religious Factors as an intervening variable is positive and significant with a T-statistic of 2.261 (> 1.96). Thus, the hypothesis $\mathrm{H} 7$ in this study which states that 'Psychological factors are mediated by Religious Factors on Community Decisions to Apply for Online Loans' is accepted.

\section{CONCLUSION}

The impact of cultural factors has a positive attitude towards people's decisions to apply for online loans. The higher the culture, the higher the community's decision to apply for online loans because this cultural factor becomes a habit that can be a role model for the people who see it. Furthermore, the psychological factors are positive but not significant to the Community's Decision to Apply for Online Loans, the higher the Personal Factors will increase the Community's Decision to Apply for Online Loans, but not only because of motivation and encouragement from one's psychology, but a more real demand is encouragement from the surrounding environment. Furthermore, the impact of cultural factors has a positive attitude towards religious factors. The higher the culture, the religious factor will increase because this cultural factor is a habit and if in the family environment only has a habit of not borrowing funds on credit due to religious and belief matters, the credit agreement will not occur. Furthermore, the positive psychological factors on the Religious Factors, the higher the Psychological Factors will increase the Religious Factors because if a person realizes that he is not allowed to do something that is prohibited by norms, especially the religious norms adopted. Furthermore, the relationship between the religious factor and the Community's Decision to Apply for Online Loans because this shows that people will be interested in Fintech products but they still consider the good and bad for themselves and their beliefs. Therefore, Fintech itself must further develop its products, especially in Indonesia, where the majority are Muslims. Therefore they must balance their products with Fintech products that are lawful for use by the public. Therefore, cultural factors and psychological factors are mediated by religious factors towards people's decisions to apply for online loans. And the next step Fintech companies must introduce more closely these Fintech products so that people can make decisions to use them

\section{REFERENCES}

[1] Pato, S. 2013. Analisis Pemberian Kredit Mikro Pada Bank Syariah Mandiri Cabang Manado. Jurnal Riset Ekonomi, Manajemen, Bisnis Dan Akuntansi.

[2] Wijaya, G., \& Sari, M. 2015. Perancangan Sistem Informasi Pengajuan Kredit Berbasis Web Pada PT . BPR Kredit Mandiri Indonesia Cabang Bekasi. IJSE - Indonesian Journal on Software Engineering.

[3] Nurina Hakim, S., \& Alyu Raj, A. 2017. Prosiding Temu Ilmiah X Ikatan Psikologi Perkembangan Indonesia Dampak kecanduan internet (internet addiction) pada remaja. Jurnal UNISSULA.

[4] Arner, D. W., Barberis, J. N., \& Buckley, R. P. 2015. The Evolution of Fintech: A New Post-Crisis Paradigm? SSRN Electronic Journal. https://doi.org/10.2139/ssrn.2676553

[5] Saputra, R., \& Semuel, H. 2013. Analisa Pengaruh Motivasi, Persepsi, Sikap Konsumen Terhadap Keputusan Pembelian Mobil Daihatsu Xenia di Sidoarjo. Jurnal Manajemen Pemasaran.

[6] Wibowo, B. 2016. Analisa regulasi fintech dalam membangun perekonomian di Indonesia. Jurnal Magister Teknik Elektro Universitas Mercu Buana.

[7] Sari, M. W., \& Novrianto, A. 2020. Analysis of factors affecting community decisions to apply for online loans (Fintech). International Journal of Advanced Science and Technology.

[8] Kolis, N. 2018. Perbankan Dalam Era Baru Digital. Economicus. 
[9] Sofyan, P. 2018. Edukasi fintech bagi masyarakat desa bojong sempu Bogor. Jurnal Bakti Masyarakat Indonesia.

[10] Muzdalifa, I., Rahma, I. A., \& Novalia, B. G. 2018. Peran Fintech Dalam Meningkatkan Keuangan Inklusif Pada UMKM Di Indonesia (Pendekatan Keuangan Syariah). Jurnal Masharif Al-Syariah: Jurnal Ekonomi Dan Perbankan Syariah. https://doi.org/10.30651/jms.v3i1.1618

[11] Khoirun Nisak. 2013. Pengaruh Pinjaman Modal Terhadap Pendapatan Usaha Mikro Kecil Dan Menengah Di Kota Mojokerto. Pendidikan Ekonomi.

[12] Arief, M. Z., \& Sutrisni, S. 2013. Praktek Rentenir Penghambat Terwujudnya Sistem Hukum Perbankan Syariah Di Kabupaten Sumenep. Performance. Jurnal Bisnis \& Akuntansi."

[13] Suharto, U. 2018. Riba and interest in Islamic finance: semantic and terminological issue. International Journal of Islamic and Middle Eastern Finance and Management. https://doi.org/10.1108/ IMEFM-08-2016-0109

[14] Mega Lestari, N. P. 2019. Pemahaman Generasi Milenial Berinvestasi di Peer to Peer Lending. Jurnal Manajemen Bisnis. https://doi.org/10.38043/ jmb.v16i3.2229

[15] Nizar, M. A. 2017. Teknologi keuangan (Fintech): Konsep dan implementasinya di Indonesia. Warta Fiskal.

[16] Dofeitner, G., Hornuf, L., Schmitt, M. \& Weber, M. 2016. The Fintech Market in Germany SSRN. Germany.

[17] Mildawati, T. 2016. Teknologi Informasi Dan Perkembangannya Di Indonesia. Ekuitas (Jurnal Ekonomi Dan Keuangan). https://doi.org/10.24034/j 25485024.y2000.v4.i2.1904

[18] siti kholifah. 2019. Tinjauan Hukum Ekonomi Islam Terhadap Transaksi Financial Technology (Fintech) Pada Layanan Peer To Peer Lending Syariah (Studi Pada Layanan Pinjaman Online PT Investree Radhika Jaya). Society.

[19] Santi, E., Budiharto, \& Saptono, H. 2017. Pengawasan Otoritas Jasa Keuangan Terhadap Financial Technology (Peraturan Otoritas Jasa Keuangan Nomor 77/Pojk.01/2016). 6(3), 1-20.

[20] Susanto, A. S. 2013. Membuat Segmentasi Berdasarkan Life Style (Gaya Hidup). Jibeka.

[21] Firdaus, D. R. S., Lubis, D. P., Susanto, D., \& Soetarto, E. 2018. Potret Budaya Masyarakat Minangkabau Berdasarkan Keenam Dimensi Budaya Hofstede (Portrait Of The Minangkabau Culture According To Hofstede's Six Cultural Dimensions). Sodality: Jurnal Sosiologi Pedesaan. https://doi.org /10 .22500/sodality.v6i2.23229

[22] Sendari, A. A. 2019. Pengertian Budaya Menurut Para Ahli, Jangan Keliru Memaknainya - Citizen6 Liputan6.com.
[23] Setiadi, Nugroho. 2003. Perilaku Konsumen: Konsep dan Implikasi untuk Strategi dan Penelitian Pemasaran.

[24] Kotler, Philip. 2005.Manajemen Pemasaran. Jilid 1 dan 2.Jakarta : PT IndeksKelompok Gramedia.

[25] Kaunang, G. 2013. Tingkat Suku Bunga Pinjaman Dan Kredit Macet Pengaruhnya Terhadap Permintaan Kredit Umkm Di Indonesia. Jurnal Riset Ekonomi, Manajemen, Bisnis Dan Akuntansi. https://doi.org/10.35794/emba.v1i3.2297

[26] Benuf, K., Mahmudah, S., \& Priyono, E. A. 2019. Perlindungan Hukum Terhadap Keamanan Data Konsumen Financial Technology Di Indonesia. Refleksi Hukum: Jurnal Ilmu Hukum, 3(2), 145-160. https://doi.org/10.24246/jrh.2019.v3.i2.p145-160

[27] Hakim Bf, A. R., Wisudawan, I. G. A., \& Setiawan, Y. 2020. Pengaturan Bisnis Pinjaman Secara Online Atau Fintech Menurut Hukum Positif Di Indonesia. Ganec Swara. https://doi.org/10.35327/gara.v14i1. 122

[28] Schiffman, Leon \& Bednall, David \& O'Cass, Aron \& Paladino, A. \& Kanuk, L. 2005. Consumer behaviour.

[29] Rijalul Alam, Naufal. (2015). Pandangan Al-Ghazali Mengenai Pendidikan Akliah (Tinjauan Teoretis dan Filosofis). Jurnal Pendidikan Agama Islam (Journal of Islamic Education Studies). 3. 346 10.15642/jpai.2015.3.2.346-367. 